\title{
Antioxidant and Antibacterial Effects of Some Medicinal Plants of Iran
}

\author{
Samira Mohammadi (iD) 1 , Khosro Piri (id)*2, Mehri Dinarvand (iD)3
}

\author{
${ }^{1}$ Department of Biotechnology, Faculty of agriculture, Buali Sina University, Hamedan, Iran \\ ${ }^{2}$ Department of Biotechnology, Faculty of agriculture, Buali Sina University, Hamedan, Iran \\ ${ }^{3}$ Forests and Rangelands Research Department, Khuzestan Agricultural and Natural Resources Research and \\ Education Center, Agricultural Research Education and Extension Organization (AREEO), Ahvaz, Iran
}

\begin{abstract}
Medicinal plants used in the treatment of diseases earlier times are potential sources of new drugs. The present study was undertaken to study the chemical composition, antioxidant and antibacterial activity of certain medicinal plants of Iran by gas chromatography and mass spectrometry (GC/MS), DPPH and disk diffusion method. According to the results of GC/MS, there are 46 kinds of chemical compounds including mucilage, fatty acids, flavonoid and diterpenes in flower of Echium khuzistanicum. There are aldehydes (7.9\%), phenols (7.5\%), fatty acids (5.8\%) and furfural (5.4\%) in the methanol extract of Echinops cephalotes. Furfural, steroids, vitamin B and flavonoids are the main compounds of Marrubium anisodon. Results of the antibacterial test showed that Staphylococcus aureus and Bacillus subtilis were more sensitive to methanol extract of Echium khuzistanicum root. Pseudomonas auruginosa was more sensitive to DMSO extract of Marrubium anisodon at $600 \mathrm{mg} / \mathrm{ml}$ concentration. Maximum flavonoid and phenol contents were belonging to Echinops cephalotes. Marrubium anisodon showed the best DPPH free radical scavenging activity.
\end{abstract}

\author{
ARTICLE HISTORY \\ Received: July 14, 2018 \\ Revised: January 02, 2019 \\ Accepted: January 07, 2019

\section{KEYWORDS} \\ Echium khuzistanicum, \\ Echinops cephalotes, \\ Marrubium anisodon, \\ Flavonoid, \\ Phenol
}

\section{INTRODUCTION}

Plants can produce a variety of chemicals so that new compounds always are discovered and extracted from plants. Each of these compounds may have therapeutic effects like antibacterial and antioxidant activities [1].

The antioxidant system in plants and animals comprise both-low molecular mass and high molecular mass antioxidants. Low molecular mass antioxidants described to date include watersoluble compounds such as reduced glutathione, ascorbic acid, and lipid-soluble ones such as carotenoids (including $\beta$-carotene), retinol, $\alpha$-tocopherol. They usually operate as free radical scavengers. Various compounds of a plant such as fibres, carotenoids, phenols, flavonoids, isoflavones ,and ascorbic acid eliminate free radicals and have antimutagenic and antioxidant activity[2]. The ability of elimination of active oxygen makes these compounds converted to factors which protect human from ailments like cancer[3]. In recent years, there are considerable attention towards the identification of plants with the antioxidant ability [4].

\footnotetext{
*CONTACT: Khosro PIRI $₫$ khpiri@gmail.com $\equiv$ Department of Biotechnology, Faculty of agriculture, Buali Sina University, Hamedan, Iran Phone: +982132527671 Fax: +982133901155
} 
Several drug resistances have been observed in human pathogenic microorganisms due to the excess usage of commercial antimicrobial drugs in the treatment of infection [5]. Also in all countries including developed countries, the prevalence of foodborne diseases are still considered a serious issue. So, a permanent search is needed to discover effective methods and materials to treat the food infection caused by microorganisms [6]. We need to identify and introduce new medicinal and aromatic plants with effective natural antibiotics, high biological value and low side effects [7].

Echium khuzistanicum Mozaff is a biennial plant of Boraginaceae family which grows in the southwest of Iran [8]. In about 150 species of Boraginaceae, naphthoquinone pigments such as alkannin and shikonin derivatives exist in roots. Alkannin (S enantiomer) and shikonin ( $\mathrm{R}$ enantiomer) and their derivatives have a lot of medicinal properties like anti-allergic, antibacterial, antiviral, antifungal, antioxidant, anti-inflammatory and wound healing [9-15]. Shikonin plays a significant role in the treatment of the obesity, intestinal ulcers, skin diseases, cancers ,and AIDS [16].

Marrubium anisodon K. Koch is a plant of the Lamiaceae. There is the various activity such as antioxidant and anti-inflammatory effect in this genus [17]. Echinops cephalotes DC is a plant of the Asteraceae. This genus is remarkable regarding chemical composition, tens of alkaloids extracted from various parts of them which used in industry, agriculture, and medicine. Alkaloids, saponins, polyphenols, carotenoids, and phytosterols were detected in this genus [18]. The aim of this study is the assessment of the chemical composition, antioxidant and antibacterial activity of these plants of Iran for the first time.

\section{MATERIAL AND METHODS}

\subsection{Plant Material}

M. anisodon and E. cephalotes were collected from the medicinal plant garden of Hamadan (Natural Resources Department, Hamedan Natural Resources and Agriculture, Education and Research Center, Medicinal Plant Garden, Hamedan, Iran) and E. khuzistanicum was planted in a greenhouse. The plant's seeds were collected from Alhaii region around Ahwaz (the southwest of Iran). The plants were identified by the botanist, Dr. Dinarvand (Faculty member, Natural Resources Department, Khuzistan Natural Resources and Agriculture, Education and Research Center, Ahvaz, Iran).

\subsection{Extraction of Plant Material}

The samples were dried at the room temperature in the dark and further was ground in a mortar. About 10 grams of each plant powder extracted in $100 \mathrm{ml}$ of methanol by soxhlet till the solvent in siphon tube of an extractor become colorless. The extract was concentrated at temperature below $40^{\circ} \mathrm{C}$ and was used for determination of flavonoids, phenols, free radical scavenging, antibacterial activity and GC/MS analysis [19].

\subsection{Determination of Total Flavonoid}

Flavonoids were determined using Aluminum chloride[20]. $0.5 \mathrm{ml}$ of extract solution $(1 \mathrm{mg} / \mathrm{ml})$ with $1.5 \mathrm{ml}$ methanol, $0.1 \mathrm{ml}$ Aluminum chloride (10\%), $0.1 \mathrm{ml}$ Potassium acetate (1M) and $2.8 \mathrm{ml}$ distilled water was mixed. After $30 \mathrm{~min}$, sample absorption was read at $415 \mathrm{~nm}$ by a double beam Lambda $45 \mathrm{UV}$-visible spectrophotometer. The total flavonoid content was determined using a standard curve of quercetin $\left(\mathrm{R}^{2}=0.981\right)$. Total flavonoid content is expressed as $\mu \mathrm{g}$ of quercetin equivalents/ $100 \mathrm{mg}$ of sample. Total flavonoid was calculated by using the following equation:

$$
\text { Absorbance }=0.0077 \text { quercetin }(\mu \mathrm{g})-0.0532
$$




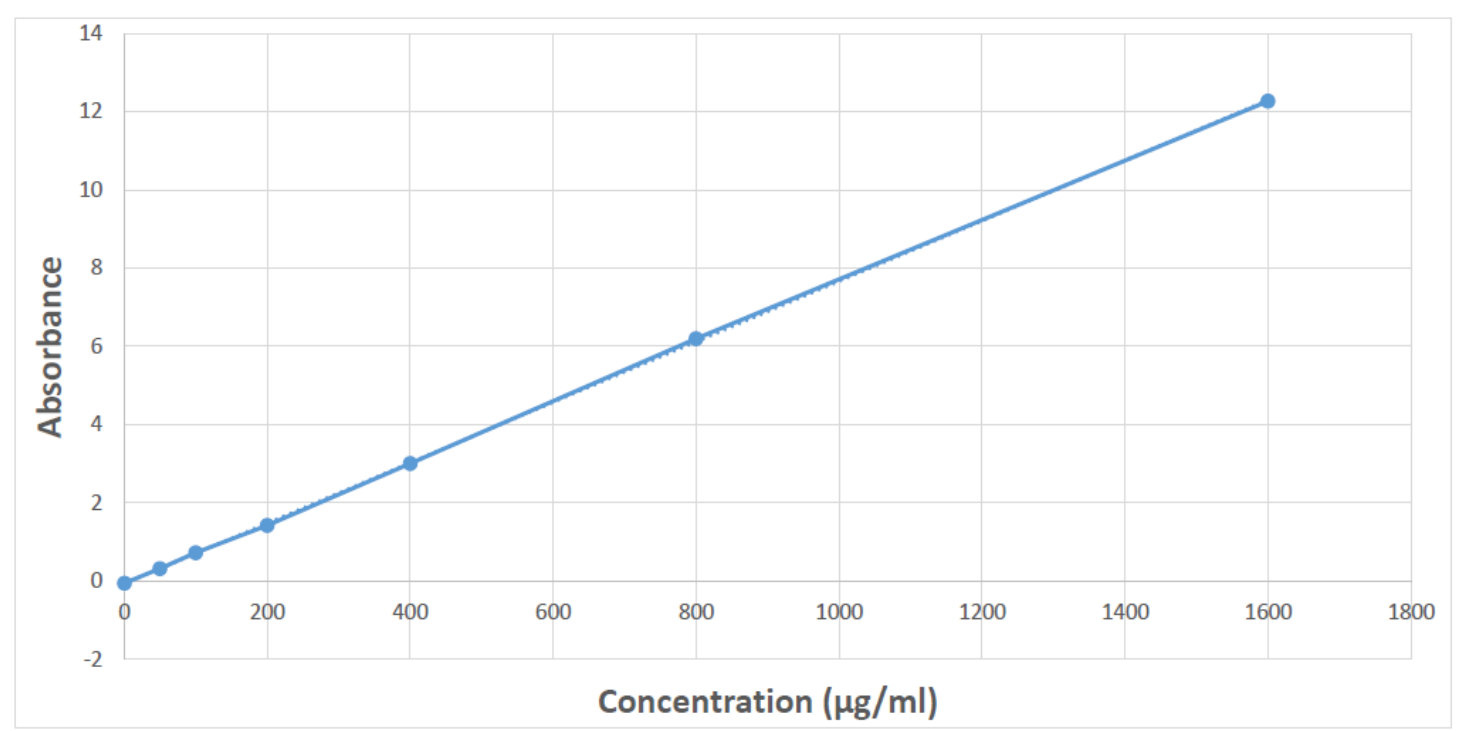

Figure 1. Quercetin standard calibration curve

\subsection{Determination of Total Phenols}

Total phenolic content in each extract was determined by using Folin-Ciocalteu reagent [21]. 200 microliter of extract $(1 \mathrm{mg} / \mathrm{ml})$ was mixed with $1 \mathrm{ml}(1 \mathrm{~N})$ Folin-Ciocalteu reagent (Sigma-Aldrich, Germany) and $5.8 \mathrm{ml}$ of distilled water, followed by $3 \mathrm{ml} 20 \%$ Sodium Carbonate $\left(\mathrm{Na}_{2} \mathrm{Co}_{3}\right) 3 \mathrm{~min}$ later. The mixture was shaken for two $\mathrm{h}$ at room temperature in the dark, and absorbance was measured at $165 \mathrm{~nm}$. All tests were performed in triplicate. Gallic acid (Sigma-Aldrich, Germany) used as a standard. The concentration of total phenolic compounds (TPC) was determined as $\mu \mathrm{g}$ gallic acid equivalents (GAE)/mg extract by using the following equation obtained from a standard gallic acid graph $\left(\mathrm{R}^{2}=0.9877\right)$ :

$$
\text { Absorbance }=0.0012 \text { gallic acid }(\mu \mathrm{g})-0.0034
$$

\subsection{Free Radical Scavenging Activity}

Free radical scavenging activity was determined by using the stable 1,1-diphenyl-2picrylhydrazyl radical (DPPH). The Ascorbic acid was used as a standard control. To study inhibition percent of DPPH, $50 \mu 1$ of the extract with different concentration $(0.2,0.4,0.6,0.8$, $1 \mathrm{mg} / \mathrm{ml})$ mixed with $5 \mathrm{ml}$ of DPPH $(0.0004 \%)$ and after $30 \mathrm{~min}$, the absorption was measured at $517 \mathrm{~nm}[22]$. The percentage of inhibition (I) was calculated as:

$$
I=\left[\left(\mathrm{A}_{\text {blank }}-\mathrm{A}_{\text {sample }}\right) / \mathrm{A}_{\text {blank }}\right]
$$

$\mathrm{IC}_{50}$ values denote the concentration of the sample, which is required to scavenge $50 \%$ of DPPH free radical.

\subsection{Assessment of Antibacterial Effects}

Six human pathogenic bacteria were used including gram-positive bacteria of Bacillus subtilis ATCC 6633, Staphylococcus aureus ATCC 6538, Streptococcus pyogenes ATCC 19615 and gram-negative bacteria of Escherichia coli ATCC 8739, Salmonella typhimurium ATCC 14028 and Pseudomonas aeruginosa ATCC 9027 prepared from Reference Center of Bu-Ali Sina Hospital (Hamedan, Iran). The antibacterial effect of the extracts was examined by the disk diffusion method. Small paper disks (prepared from Padtan Teb Co. with a diameter of $6.4 \mathrm{~mm}$ ) soaked in different concentration of the plant extract with 100,200 and $600 \mathrm{mg} / \mathrm{ml}$ concentration. In this method, a suspension with the dilution equal to $0.5 \mathrm{McF}$ arland standard was prepared by 24-hour culture of bacteria. At the next stage, $0.2 \mathrm{ml}$ of the bacterial suspension 
was added to each plate and surface-cultured by a sterile swab [23]. Then the disc containing $20 \mu \mathrm{l}$ of the extract was placed on the medium using sterile forceps tip. The plates were incubated for 24 hours at $37^{\circ} \mathrm{C}$ [24]. The solvent was only used as the negative control and ten $\mu \mathrm{g}$ antibiotic gentamicin disc (Padtan Teb Co.) as the positive control. After incubation, the diameter of the inhibition halo was measured using a ruler and recorded. The antibacterial test of the extracts was done in triplicate for each concentration, and completely randomized design and ANOVA test were employed at 5\% level. The results were expressed in means \pm SEs.

\subsection{Gas Chromatography and Mass Spectrometry}

The chemical composition of the extracts was identified by GC/MS (Agilent 6890N gas chromatography coiled with Agilent $5973 \mathrm{~N}$ mass detector). $1 \mu 1$ of each extract was injected. The separation of extract was performed using an HP-5 column of $30 \mathrm{~m}$ in length and $0.25 \mathrm{~mm}$ in diameter and $0.25 \mu \mathrm{m}$ in stationary phase thickness. The analysis conditions were shown in Table 1.

Table 1. Temperature program of analysis

\begin{tabular}{lll}
\hline Rate $\left({ }^{\circ} \mathrm{C} / \mathrm{min}\right)$ & Temperature ${ }^{\circ} \mathrm{C}$ & Hold $(\mathrm{min})$ \\
\hline- & 60.00 & 0.00 \\
\hline 5.00 & 150.00 & 0.00 \\
\hline 10.00 & 250.00 & 0.00 \\
\hline
\end{tabular}

The solvent delay was $5 \mathrm{~min}$, and the identification of the compound was based on comparing their mass spectra with those recorded in the Wiley $7 \mathrm{n}$ mass spectra database and with literature reports.

\subsection{Statistical Analysis}

All the experiments did with three replicates for each sample of plants. A completely randomized design was employed at $1 \%$ level.

\section{RESULTS}

\subsection{Chemical Composition of Plant Extracts}

To analyze results accurately and given that the chemical composition of these plants is not detected, after extraction, chemical composition of plants were checked by GC/MS. The amount and type of chemical compounds were achieved by comparing the data from GC/MS with information of libraries.

\subsection{Chemical Composition of Marrubium anisodon}

In methanol extract of this plant's aerial parts, 86 compounds were identified by GC/MS (Figure 2). The compounds present in this plant (with more than one percent), their retention time (RT), molecular formula, molecular weight (MW), and concentration (peak area \%) are presented in Table 2. Furfural, steroids, vitamin B and flavonoids are the main compounds of M. anisodon. According to the results, furfural is the most abundant compound $(20.43 \%)$. Furfural is the natural product of lignocellulose degradation. Also, furfural is obtained from dehydration of pentose sugars during cellulose depolymerization under acidic conditions [25]. Furfural and its derivatives are the main flavors of foods. Furfural at low concentrations (1-12 $\mathrm{mM}$ ) inhibits microorganisms [26]. About $13.26 \%$ of this plant extract is cyclopentane which is in steroid structure. The extract consists of lactose (9.53\%) and inositol vitamin (8.55\%). This plant extract has flavonoids such as $4 \mathrm{H}$-pyran-4-one $(5.42 \%)$. Fatty acids such as the dodecanoic acid (1.036\%) and pentadecanoic acid (1.55\%), alkaloids such as alpha-pyrrolidone $(2.21 \%)$ and cyclic isoprenoids such as cyclotetradecan $(2.32 \%)$ were detected by GC/MS. 
Previous studies have reported that there are some compounds such as diterpenes, sterol, derivatives of caffeic acid and flavonoids in this genus [27]. One acylated flavonoid glycoside and two tetrasaccharides phenylethanoid glycosides, velutinosides I-II, have been isolated from Marrubium velutinum shoot [28]. Marrusidins A and B are two labdane-type diterpenes isolated from the chloroform extract of Marrubium anisodon along with polyodonine [29]. The methanol extract of the plant showed a $27.7 \%$ inhibitory activity of acetylcholine esterase used for the treatment of the disease Alzheimer. This inhibitory effect was attributed to the components that are functionally or structurally similar to tacrine [30]. According to the results of GC / MS, it is possible that this effect of the plant is related to alkaloids such as alphapyrrolidine, which need to be tested, and confirmed in the laboratory. This family plants have been used to treat dandruff and hair regrowth [31]. According to the presence of vitamin B7 in this plant, it can be concluded that this plant is a good candidate for the treatment of hair loss and alopecia.

\subsection{Chemical Composition of Echium Khuzistanicum (Flowers)}

According to GC/MS results, 46 compounds were found in the methanol extract of $E$. khuzistanicum flower. Each of these compounds made a peak on chromatogram (Figure 3). The plant compounds with more than $1 \%$ are shown in Table 3 including the mucilage, fatty acids, flavonoids and diterpenes. According to the results, glucose is the highest compound in the flower extract of this plant (22.32\%). Mucilage in Borago officinalis is hydrolyzed to glucose, galactose, arabinose and allantoin [32-36] so the glucose present in the extract of this plant can be obtained by hydrolysis of mucilage [37]. Mucilages are carbohydrates with very complex chemical structures and high molecular weights. One of the most important medicinal properties of the mucilage is their anti-inflammatory property. It is used to treat gastrointestinal ulcers (stomach and intestines) and infections of the throat mucous [38]. In flower extract of this plant, $11.23 \%$ of $9,12,15$-octadecatrien-1-ol was found. This compound is also present in the spartium junceam extract. Fatty acids such as a capric acid (12.6\%), octadecanoic acid

Table 2. The compounds present in M. anisodon (more than 1\%)

\begin{tabular}{llllll}
\hline No. & Name of the compounds & $\mathrm{RT}^{\mathrm{a}}$ & $\mathrm{MF}^{\mathrm{b}}$ & $\mathrm{MW}^{\mathrm{c}} \mathrm{g} / \mathrm{mol}$ & Peak area\% \\
\hline 1 & Furancarboxaldehyde & 13.63 & $\mathrm{C}_{5} \mathrm{H}_{4} \mathrm{O}_{2}$ & 96.09 & 20.43 \\
\hline 2 & Cyclopentane & 26.41 & $\mathrm{C}_{5} \mathrm{H}_{10}$ & 70.1 & 13.26 \\
\hline 3 & Lactose & 26.64 & $\mathrm{C}_{12} \mathrm{H}_{22} \mathrm{O}_{11}$ & 342.3 & 9.53 \\
\hline 4 & Neo-inositole & 24.86 & $\mathrm{C}_{6} \mathrm{H}_{12} \mathrm{O}_{6}$ & 180.16 & 8.55 \\
\hline 5 & 4H-pyran-4-one & 11.08 & $\mathrm{C}_{5} \mathrm{H}_{4} \mathrm{O}_{2}$ & 96.085 & 5.42 \\
\hline 6 & $\begin{array}{l}\text { 12-methyl-E,E-2,13- } \\
\text { octadecadien-1-ol }\end{array}$ & 20.09 & $\mathrm{C}_{19} \mathrm{H}_{36} \mathrm{O}$ & 280.496 & 3.22 \\
\hline 7 & Cyclotetradecan & 16.17 & $\mathrm{C} 14 \mathrm{H} 28$ & 196.37 & 2.32 \\
\hline 8 & Alpha-pyrrolidone & 9.21 & $\mathrm{C}_{4} \mathrm{H}_{7} \mathrm{NO}$ & 85.106 & 2.21 \\
\hline 9 & Propanoic acid & 8.05 & $\mathrm{C}_{3} \mathrm{H}_{6} \mathrm{O}_{2}$ & 74.07854 & 1.88 \\
\hline 10 & Pentadecanoic acid & 25.11 & $\mathrm{C}_{15} \mathrm{H}_{30} \mathrm{O}_{2}$ & 242.3975 & 1.55 \\
\hline 11 & Dodecanoic acid & 24.47 & $\mathrm{C}_{12} \mathrm{H}_{24} \mathrm{O}_{2}$ & 200.32 & 1.03 \\
\hline
\end{tabular}

a: Retention Time, b: Molecular Formula, c: Molecular Weight 


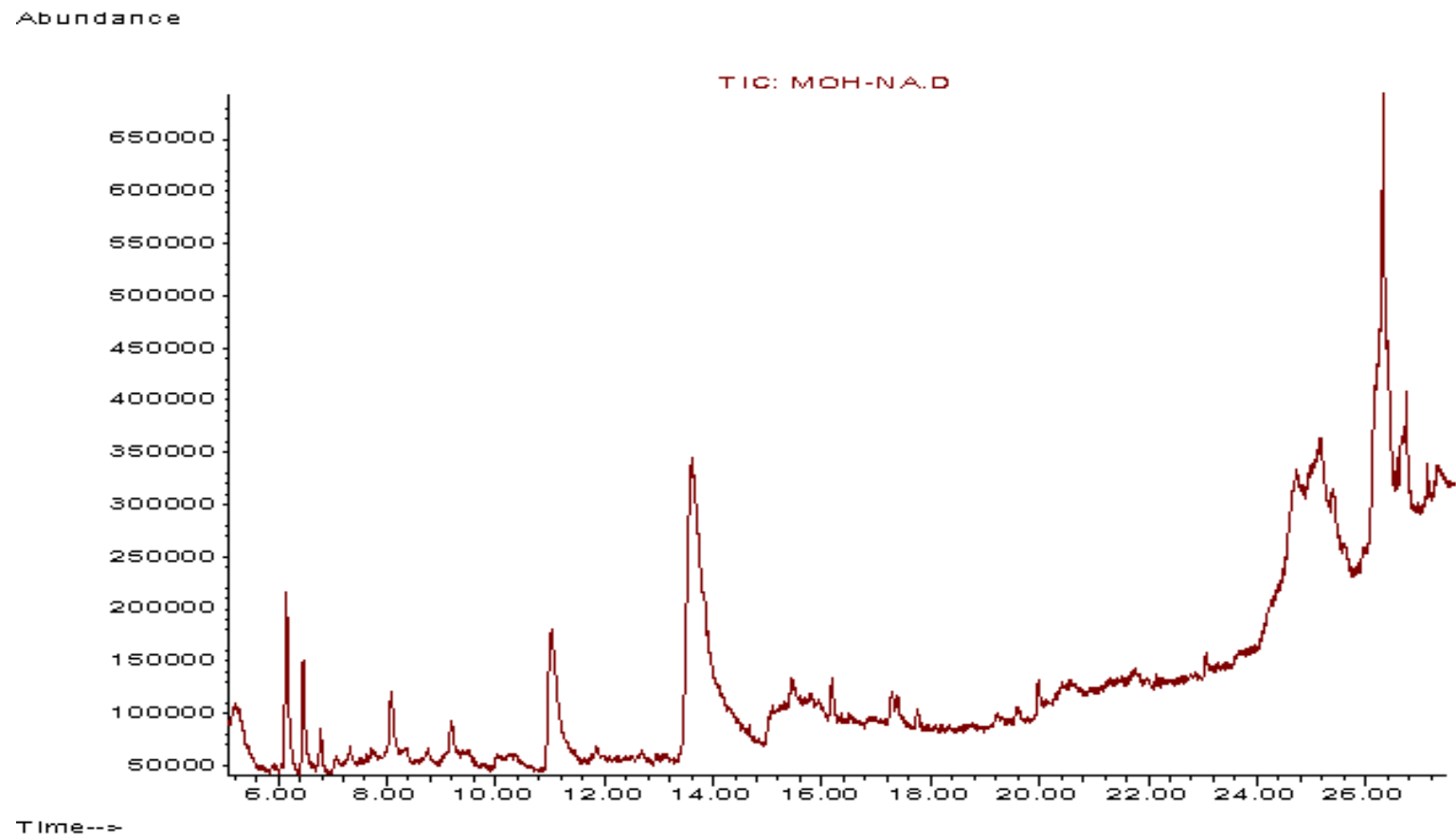

Figure 2. The chromatogram of M. anisodon

(3.75\%) and butanoic acid (1.62\%), alkaloids such as indole (2.57\%), phenolic compounds such as 4-vinyl-2-methoxy-phenol (4.4\%), diterpenes such as phytol (5.7\%) and flavonoids such as 4 H-Pyran-4-one $(1.91 \%)$ and 3-Hepten-2-one $(1.54 \%)$ are found in the extract. Capric acid is a 10-carbon fatty acid found in palm and coconut oil and less in animal fats and milk. This oil reduces insulin resistance and balances insulin level in humans. 36.7\% of furfural and $1.99 \%$ of the sulfur compound such as dimethyl sulphone compound are also found in this plant. It is used as a food additive to maintain the quality and taste of food and treat parasitic infections and carriers of drugs (Jacob et al., 1999). Researchers try to increase the level of this fatty acid in transgenic plants [39]. Diterpene available in this plant is an alcoholic non-cyclic diterpene with antibacterial, anticancer, anti-inflammatory and diuretic effects (Furumoto, 2002). Delorme et al. (1977) reported that Echium amoenum has anthocyanins $(13 \%)$, flavonoids $(0.15 \%)$ and a small amount of alkaloids [40]. Javadzade (1995) reported that Borago officinalis have mucilage, tannins, $\mathrm{Na}, \mathrm{Ca}$ and $\mathrm{K}$. Due to the presence of different materials such as mucilage, flavonoids, phenolic compounds, diterpenes and useful fatty acids in this plant, it could be a good candidate for the treatment of many diseases and it is necessary to examine the effects of secondary metabolites of this plant.

\subsection{Chemical composition of Echinops cephalotes}

According to the results, 76 kinds of the chemical compounds found in the methanol extract of E. cephalotes (Figure 4). The compounds present in this plant (with more than one percent), their retention time (RT), molecular formula, molecular weight (MW), and concentration (peak area \%) are presented in Table 4. Aldehydes (7.9\%), coniferol (4.8\%), fatty acids $(5.8 \%)$ and furfural $(5.4 \%)$ are found in E. cephalotes. According to the results, tridecanedinal is the most abundant compound in this plant $(7.9 \%)$. The presence of alkaloids, saponins, plant sterols, polyphenols, and carotenoids has been detected in different parts of the echinops genus [18]. Diisodecyl ether compound derived from streptomyces had the antibacterial effect and was found in this plant [41]. Benzenemethanol is a type of benzyl alcohol present in many plants and an aglycone with antioxidant effect [42]. There are toxic compounds such as DDMP and benzyl alcohol in this plant so it is necessary to examine its toxicity. 


\subsection{Total phenol and flavonoids}

The total phenol content in the samples varied from 21.24 to $177.19 \mu \mathrm{g}$ gallic acid $/ \mathrm{mg}$ dr.wt. Maximum amount phenol was found in E. cephalotes while the lowest amount was observed in the shoot of E. khuzistanicum.

Flavonoids are regarded as one of the most widespread group of natural constituents found in plants. The value of flavonoid content varied from 323.59 to $1305.61 \mu \mathrm{g} \mathrm{QC} / 100 \mathrm{mg}$ dr.wt. Maximum flavonoid content was determined in E. cephalotes and leaves of $E$. khuzistanicum (Table 5).

\subsection{DPPH}

The antioxidants are known to mediate their effect by directly reacting with ROS quenching them and chelating the catalytic metal ions. The radical scavenging activity was found to be high in M. anisodon followed by the flower of E. khuzistanicum (Table 6). $\mathrm{IC}_{50}$ values in M. anisodon and the flower of E. khuzistanicum are lower than ascorbic acid.

\subsection{Antibacterial Effects}

Data statistical analysis showed a significant difference at the level of 1\%. In Tables 710 , the diameter of the halo preventing the growth in the presence of the extracts is shown. Gentamycin was a positive control (Table 11).

\subsection{Antibacterial Effects of Echium Khuzistanicum}

The methanol extract of the root had maximum inhibition of gram-positive bacteria Staphylococcus aureus and Bacillus subtilis. The growth inhibition was increased by increasing the extracts' concentration. Bacillus subtilis halo diameter in the presence of methanol extract of the root was $24.33 \pm 0.57$, and in the bacteria, Staphylococcus aureus was equal to $24.16 \pm 1.6$. These halos' diameter were also bigger than with the positive control (Gentamicin). The extracts had the lowest effect on Pseudomonas aeruginosa.

Table 3. The compounds present in E. khuzistanicum (more than 1\%)

\begin{tabular}{llllll}
\hline No. & Name of the compounds & $\mathrm{RT}^{\mathrm{a}}$ & $\mathrm{MF}^{\mathrm{b}}$ & $\mathrm{MW}^{\mathrm{c}} \mathrm{g} / \mathrm{mol}$ & Peak area\% \\
\hline 1 & alpha-D-Glucopyranoside & 20.43 & $\mathrm{C}_{7} \mathrm{H}_{14} \mathrm{O}_{6}$ & 194.1825 & 22.32 \\
\hline 2 & Decanoic acid & 25.57 & $\mathrm{C}_{10} \mathrm{H}_{20} \mathrm{O}_{2}$ & 172.268 & 12.60 \\
\hline 3 & $9,12,15-$ Octadecatrien-1-ol & 25.81 & $\mathrm{C}_{18} \mathrm{H}_{32} \mathrm{O}$ & 264.453 & 11.23 \\
\hline 4 & 2-Furancarboxaldehyde & 13.83 & $\mathrm{C}_{5} \mathrm{H}_{4} \mathrm{O}_{2}$ & 96.09 & 7.36 \\
\hline 5 & Phytol & 18.57 & $\mathrm{C}_{20} \mathrm{H}_{40} \mathrm{O}$ & 296.539 & 5.7 \\
\hline 6 & 4-vinyl-2-methoxy-phenol & 11.26 & $\mathrm{C}_{9} \mathrm{H}_{10} \mathrm{O}_{2}$ & 150.18 & 4.40 \\
\hline 7 & d-Talonic acid lactone & 12.31 & $\mathrm{C}_{6} \mathrm{H}_{10} \mathrm{O}_{6}$ & 178.14 & 4 \\
\hline 8 & Octadecanoic acid & 26.28 & $\mathrm{C}_{18} \mathrm{H}_{36} \mathrm{O}_{2}$ & 284.48 & 3.75 \\
\hline 9 & Indole & 9.07 & $\mathrm{C}_{8} \mathrm{H}_{7} \mathrm{~N}$ & 117.15 & 2.57 \\
\hline 10 & Dimethyl sulfone & 13.62 & $\mathrm{C}_{2} \mathrm{H}_{6} \mathrm{O}_{2} \mathrm{~S}$ & 94.13 & 1.99 \\
\hline 11 & 4H-Pyran-4-one & 13.79 & $\mathrm{C}_{5} \mathrm{H}_{4} \mathrm{O}_{2}$ & 96.085 & 1.91 \\
\hline 12 & Butanoic acid & 11.06 & $\mathrm{C}_{4} \mathrm{H}_{8} \mathrm{O}_{2}$ & 88.11 & 1.62 \\
\hline 13 & 3-Hepten-2-one & 21.61 & $\mathrm{C}_{7} \mathrm{H}_{12} \mathrm{O}$ & 112.172 & 1.54 \\
\hline a: Retention Time, b: Molecular Formula, c: Molecular $\mathrm{Weight}_{2}$ & &
\end{tabular}




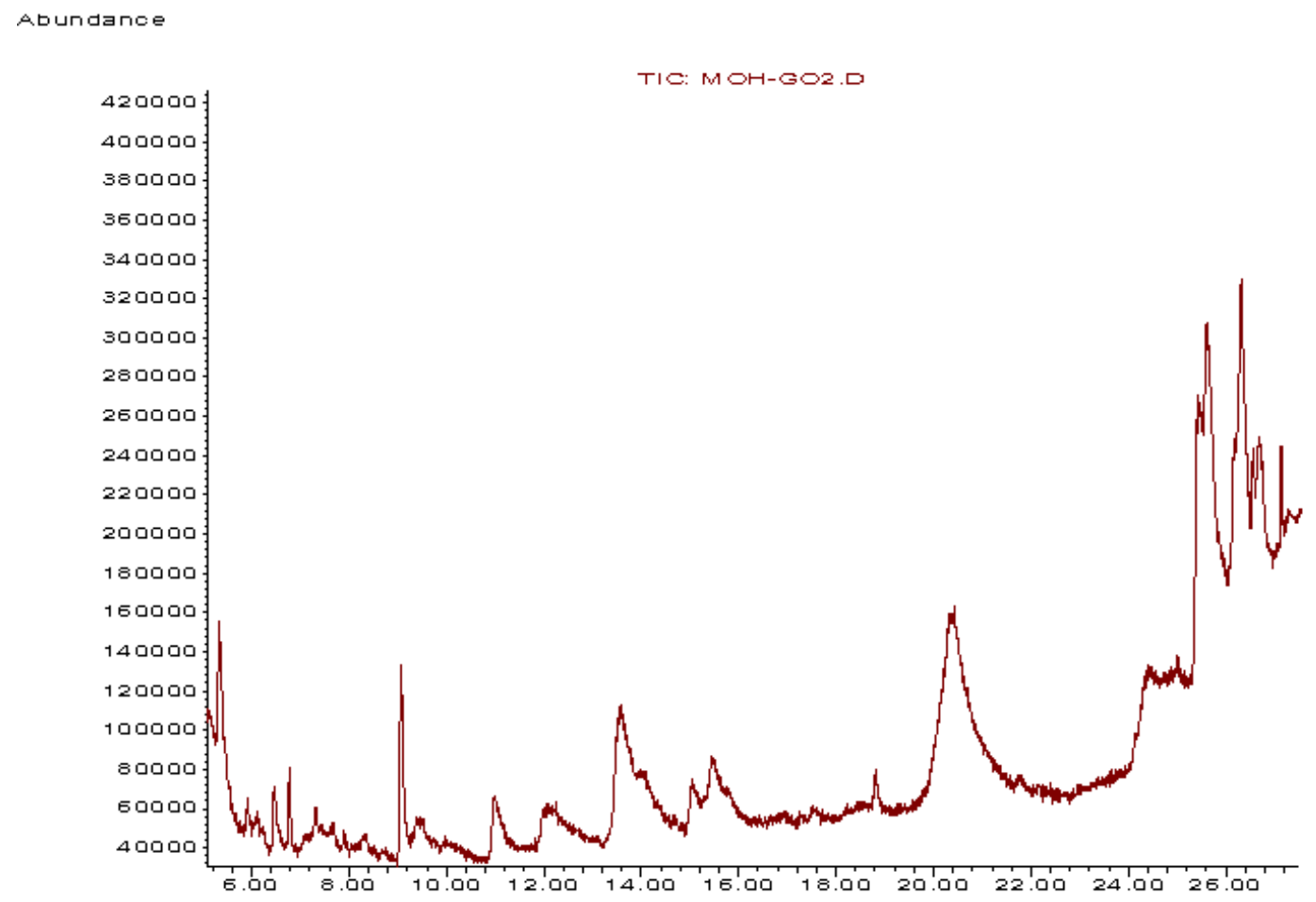

TIme-=-

Figure 3. The chromatogram of E. khuzistanicum

Table 4. The compounds present in E. cephalotes (more than 1\%)

\begin{tabular}{llllll}
\hline No. & Name of the compounds & $\mathrm{RT}^{\mathrm{a}}$ & $\mathrm{MF}^{\mathrm{b}}$ & $\begin{array}{l}\mathrm{MW}^{\mathrm{c}} \\
\mathrm{g} / \mathrm{mol}\end{array}$ & Peak area\% \\
\hline 1 & Tridecanedial & 26.47 & $\mathrm{C}_{13} \mathrm{H}_{24} \mathrm{O}_{2}$ & 212.333 & 7.9 \\
\hline 2 & Capronic acid & 25.14 & $\mathrm{C}_{6} \mathrm{H}_{12} \mathrm{O}_{2}$ & 116.16 & 5.82 \\
\hline 3 & $\begin{array}{l}\text { 11,13-Dimethyl-12-tetradecen-1-ol } \\
\text { acetate }\end{array}$ & 27.13 & $\mathrm{C}_{18} \mathrm{H}_{34} \mathrm{O}_{2}$ & 282.4614 & 5.76 \\
\hline 4 & 2-Furancarboxaldehyde & 13.83 & $\mathrm{C}_{5} \mathrm{H}_{4} \mathrm{O}_{2}$ & 96.09 & 5.46 \\
\hline 5 & Octadecanoic acid & 26.47 & $\mathrm{C}_{18} \mathrm{H}_{36} \mathrm{O}_{2}$ & 284.48 & 4.91 \\
\hline 6 & Coniferol & 25.61 & $\mathrm{C}_{10} \mathrm{H}_{12}$ & 180.201 & 4.87 \\
\hline 7 & Phytol & 18.57 & $\mathrm{C}_{20} \mathrm{H}_{40} \mathrm{O}$ & 296.539 & 4.15 \\
\hline 8 & 2,2,3-Trimethyloxirane & 11.21 & $\mathrm{C}_{5} \mathrm{H}_{10} \mathrm{O}$ & 86.132 & 4.08 \\
\hline 9 & 2-Ethyl-2-hexen-1-ol & 25.43 & $\mathrm{C}_{8} \mathrm{H}_{16} \mathrm{O}$ & 128.212 & 3.47 \\
\hline 10 & Benzenemethanol & 24.38 & $\mathrm{C}_{7} \mathrm{H}_{10} \mathrm{O}$ & 110.156 & 2.94 \\
\hline 11 & 2-Methyl-2-pentenal & 13.90 & $\mathrm{C}_{6} \mathrm{H}_{10} \mathrm{O}$ & 98.145 & 2.59 \\
\hline 12 & Hexanoic acid & 24.52 & $\mathrm{C}_{6} \mathrm{H}_{12} \mathrm{O}_{2}$ & 116.16 & 2.22 \\
\hline 13 & 1-Methoxy-3-hydroxy methyl octane & 24.81 & $\mathrm{C}_{10} \mathrm{H}_{22} \mathrm{O}_{2}$ & 174.281 & 2.13 \\
\hline
\end{tabular}

a: Retention Time, b: Molecular Formula, c: Molecular Weight 


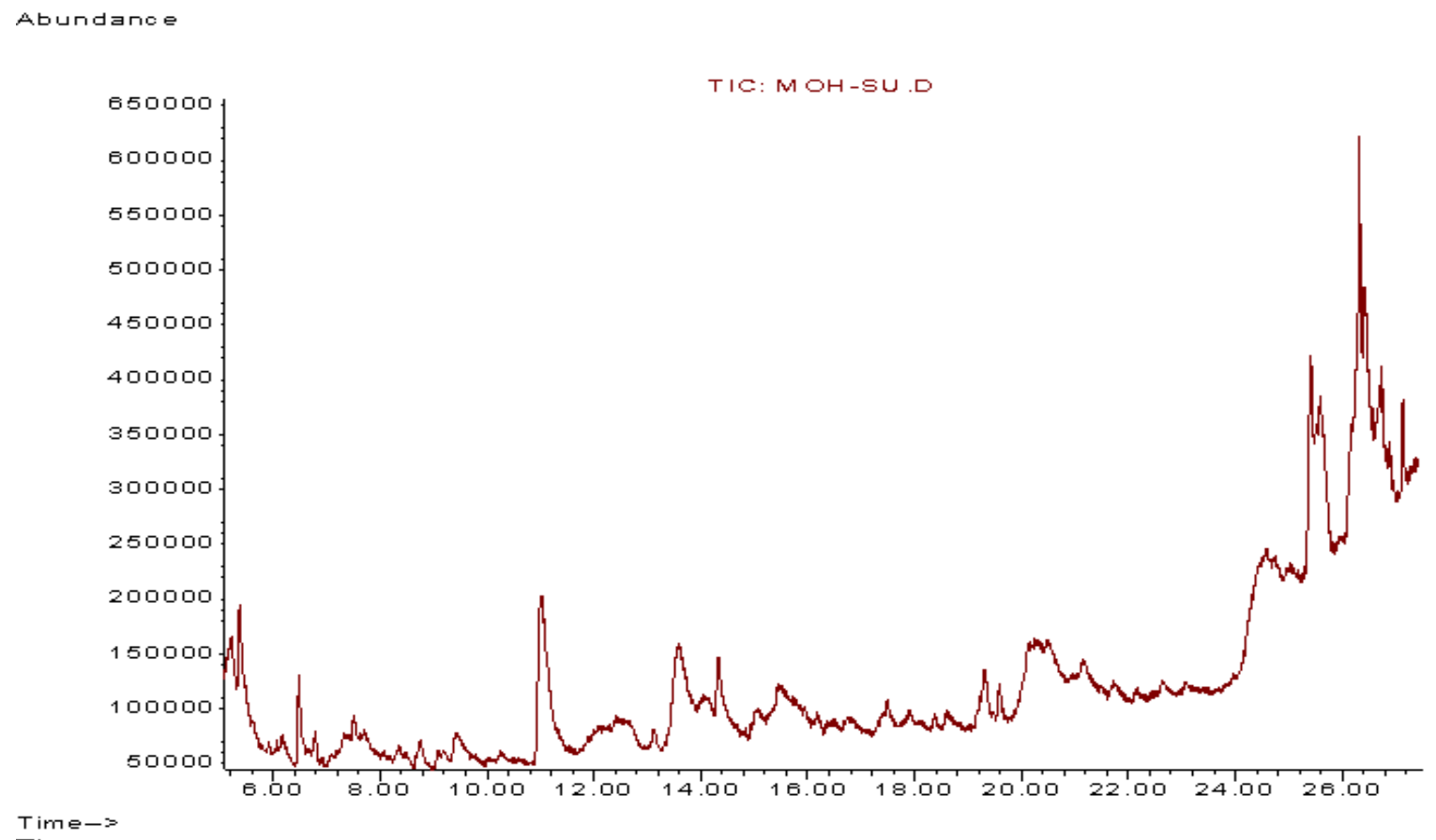

Time->

Figure 4. The chromatogram of E. cephalotes

Table 5. The total phenol content ( $\mu$ g gallic acid/mg dr.wt) and the total flavonoid content ( $\mu \mathrm{g} \mathrm{QC} / 100$ mg dr.wt)

\begin{tabular}{|c|c|c|c|c|c|c|}
\hline $\begin{array}{l}\text { Plant } \\
\text { sample }\end{array}$ & E. cephalotes & $\begin{array}{c}\text { E. khuzistanicum } \\
\text { Leaf }\end{array}$ & $\begin{array}{c}\text { E. khuzistanicum } \\
\text { Root }\end{array}$ & $\begin{array}{c}\text { E. khuzistanicum } \\
\text { Shoot }\end{array}$ & $\begin{array}{c}\text { E. khuzistanicum } \\
\text { flower }\end{array}$ & M. anisodon \\
\hline $\begin{array}{l}\text { Phenol } \\
\text { content }\end{array}$ & $177 / 19 \pm 7.49^{\mathrm{a}}$ & $60.96 \pm 1.16^{c}$ & $28.13 \pm 0.82^{\mathrm{d}}$ & $21.24 \pm .083^{\mathrm{d}}$ & $73.71 \pm 2.44^{c}$ & $109.8 \pm 6.5^{b}$ \\
\hline $\begin{array}{l}\text { Flavonoid } \\
\text { content }\end{array}$ & $1305.61^{\mathrm{a}}$ & $1305.61^{\mathrm{a}}$ & $323.59 \pm 4.52^{\mathrm{b}}$ & $336.91 \pm 4.52^{b}$ & $543.69 \pm 20.61^{b}$ & $369.18 \pm 6.75^{b}$ \\
\hline
\end{tabular}

Table 6. The inhibition percent (I) and $\mathrm{IC}_{50}$

\begin{tabular}{cccccccc}
\hline $\begin{array}{c}\text { Variable } \\
\mathrm{s}\end{array}$ & $\begin{array}{c}\text { Ascorbic } \\
\text { acid }\end{array}$ & $\begin{array}{c}\text { E. cephalotes } \\
\text { E. khuzistanicum } \\
\text { Leaf }\end{array}$ & $\begin{array}{c}\text { E. khuzistanicum } \\
\text { Root }\end{array}$ & $\begin{array}{c}\text { E. khuzistanicum } \\
\text { Shoot }\end{array}$ & $\begin{array}{c}\text { Ehuzistanicum } \\
\text { flower }\end{array}$ & M. anisodon \\
\hline $\mathrm{I}$ & $95.92 \pm 0.72^{\mathrm{a}}$ & $7 / 26 \pm 0.72^{\mathrm{e}}$ & $13.6 \pm 0.46^{\mathrm{e}}$ & $69.36 \pm 0.30^{\mathrm{d}}$ & $69.08 \pm 0.08^{\mathrm{d}}$ & $71.23 \pm 0.28^{\mathrm{c}}$ & $72.48 \pm 0.24^{\mathrm{b}}$ \\
\hline $\begin{array}{c}\mathrm{IC}_{50} \\
(\mathrm{mg} / \mathrm{ml})\end{array}$ & 0.39 & 6.94 & 3.67 & 0.72 & 0.72 & 0.14 & 0.14 \\
\hline
\end{tabular}


Table 7. The diameters of clear zone ( $\mathrm{mm})$ in the presence of E. khuzistanicum shoot extracts

\begin{tabular}{lccccccccc}
\hline \multirow{2}{*}{ Bacterium } & \multicolumn{3}{c}{ Methanol } & \multicolumn{3}{c}{ Concentration $(\mathrm{mg})$} & \multicolumn{1}{c}{ DMSO } \\
\cline { 2 - 11 } & 100 & 200 & 400 & 100 & 200 & 400 & 100 & 200 & 400 \\
\hline S. aureus & 0 & $10.5 \pm 0.96$ & $20.33 \pm 1.02$ & 0 & 0 & $11.83 \pm 0.76$ & $8.83 \pm 1.04$ & $11.5 \pm 0.5$ & $13.5 \pm 0.5$ \\
\hline B. subtilis & 0 & $8.5 \pm 1$ & $20.83 \pm 0.28$ & 0 & 0 & 0 & $8.5 \pm 0.5$ & $10.5 \pm 0.5$ & $12.83 \pm 0.76$ \\
\hline S. pyogenes & 0 & $8.5 \pm 0.5$ & $14 \pm 1$ & 0 & 0 & 0 & 0 & 0 & 0 \\
\hline E. coli & $8.23 \pm 0.25$ & $16.83 \pm 1.06$ & $23.5 \pm 0.78$ & 0 & 0 & $12.83 \pm 0.28$ & 0 & 0 & 0 \\
\hline$P$. aeruginosa & 0 & 0 & $10 \pm 0.5$ & 0 & 0 & $11.83 \pm 0.76$ & 0 & 0 & 0 \\
\hline S. typhimurium & $7.96 \pm 1.37$ & $15 \pm 1$ & $20.5 \pm 1.32$ & 0 & 0 & $12.83 \pm 0.28$ & 0 & 0 & $12.83 \pm 0.28$ \\
\hline
\end{tabular}

Table 8. The diameters of clear zone (mm) in the presence of E. khuzistanicum leaf extracts

\begin{tabular}{|c|c|c|c|c|c|c|c|c|c|}
\hline \multirow{3}{*}{ Bacterium } & \multicolumn{3}{|c|}{ Methanol } & \multicolumn{3}{|c|}{ Ethanol } & \multicolumn{3}{|c|}{ DMSO } \\
\hline & \multicolumn{9}{|c|}{ Concentration (mg) } \\
\hline & 100 & 200 & 400 & 100 & 200 & 400 & 100 & 200 & 400 \\
\hline S. aureus & 0 & 0 & $11.5 \pm 1.32$ & 0 & $8.5 \pm 0.5$ & $11.83 \pm 0.28$ & 0 & $9.5 \pm 1.8$ & $14.5 \pm 0.5$ \\
\hline B. subtilis & 0 & $6.66 \pm 0.57$ & $11.16 \pm 0.76$ & $7.16 \pm 0.28$ & $7.83 \pm 0.28$ & $12.16 \pm 0.28$ & 0 & $17.83 \pm 1.2$ & $20 \pm 1$ \\
\hline S. pyogenes & 0 & 0 & 0 & 0 & 0 & 0 & 0 & 0 & 0 \\
\hline E. coli & 0 & 0 & $11.16 \pm 1.75$ & \pm 0.58 & \pm 0.59 & $13.5 \pm 0.5$ & $8.16 \pm 0.28$ & $10.33 \pm 1.1$ & $16.16 \pm 0.3$ \\
\hline P. aeruginosa & 0 & 0 & $8 \pm 0.5$ & 0 & 0 & 0 & 0 & 0 & $8.16 \pm 0.28$ \\
\hline S. typhimurium & 0 & 0 & $17 \pm 1.32$ & 0 & $9.66 \pm 0.28$ & $16.66 \pm 0.76$ & $8.66 \pm 0.28$ & $13 \pm 0.5$ & $15.16 \pm 1.6$ \\
\hline
\end{tabular}

Table 9. The diameters of clear zone ( $\mathrm{mm})$ in the presence of E.khuzistanicum flower extracts

\begin{tabular}{lccccccccc}
\hline \multicolumn{7}{c}{ Methanol } & \multicolumn{7}{c}{ Ethanol } \\
\hline Bacterium & \multicolumn{7}{c}{ Concentration (mg) } \\
\hline \multicolumn{1}{c}{100} & 200 & 400 & 100 & 200 & 400 & 100 & 200 & 400 \\
\hline S. aureus & 0 & $8.5 \pm 0.5$ & $9.83 \pm 0.28$ & 0 & $7.5 \pm 0.5$ & $9.33 \pm 0.28$ & 0 & $12.16 \pm 1.75$ & $16.33 \pm 0.76$ \\
\hline B. subtilis & 0 & 0 & $10.83 \pm 0.76$ & 0 & 0 & 0 & 0 & $18.33 \pm 0.28$ & $11.5 \pm 0.5$ \\
\hline S. pyogenes & 0 & $8.83 \pm 0.76$ & $9.5 \pm 0.5$ & 0 & 0 & 0 & 0 & 0 & 0 \\
\hline E. coli & 0 & 0 & 0 & 0 & 0 & 0 & 0 & $8.66 \pm 0.28$ & $10.83 \pm 0.76$ \\
\hline P. aeruginosa & 0 & 0 & 0 & 0 & 0 & 0 & 0 & 0 & 0 \\
\hline S. typhimurium & 0 & 0 & 0 & 0 & 0 & 0 & $9.66 \pm 0.76$ & $14 \pm 1$ & $15.66 \pm 0.57$ \\
\hline
\end{tabular}


Table 10. The diameters of clear zone $(\mathrm{mm})$ in the presence of E. khuzistanicum root extracts

\begin{tabular}{|c|c|c|c|c|c|c|c|c|c|}
\hline \multirow{3}{*}{ Bacterium } & \multicolumn{3}{|c|}{ Methanol } & \multicolumn{3}{|c|}{ DMSO } & \multicolumn{3}{|c|}{ Ethanol } \\
\hline & \multicolumn{9}{|c|}{ Concentration (mg) } \\
\hline & 100 & 200 & 400 & 100 & 200 & 400 & 100 & 200 & 400 \\
\hline S. aureus & $12.16 \pm 1.6$ & $16.16 \pm 1.89$ & $24.16 \pm 1.6$ & $10.83 \pm 0.76$ & $14.5 \pm 0.5$ & $20.83 \pm 0.76$ & 0 & 0 & 0 \\
\hline B. subtilis & 0 & $13.16 \pm 0.76$ & $24.33 \pm 0.57$ & \pm 110 & $14.33 \pm 2.08$ & $21.66 \pm 1.15$ & 0 & 0 & 0 \\
\hline S. pyogenes & $9.66 \pm 0.28$ & $13.66 \pm 0.57$ & $21.83 \pm 0.76$ & 0 & $10 \pm 0.5$ & $13.16 \pm 0.76$ & 0 & 0 & 0 \\
\hline E. coli & 0 & $11.83 \pm 0.76$ & $18.66 \pm 0.78$ & $9.66 \pm 0.57$ & $15.16 \pm 0.28$ & $19.33 \pm 1.52$ & 0 & 0 & 0 \\
\hline P. aeruginosa & 0 & 0 & $12.66 \pm 1.06$ & 0 & 0 & $8.16 \pm 0.28$ & 0 & 0 & 0 \\
\hline S. typhimurium & $10.83 \pm 0.76$ & $17.5 \pm 0.5$ & $21 \pm 1$ & $13.5 \pm 0.5$ & $18.83 \pm 0.76$ & $22 \pm 0.5$ & 0 & 0 & 0 \\
\hline
\end{tabular}

Table 11. The diameters $(\mathrm{mm})$ in the presence of the gentamicin antibiotic as a positive control.

\begin{tabular}{ll}
\hline Bacterium & Diameter $(\mathrm{mm})$ \\
\hline S. aureus & $17.5 \pm 0.76$ \\
\hline B. subtilis & $20.83 \pm 0.28$ \\
\hline S. pyogenes & $19 \pm 0.18$ \\
\hline E. coli & $16.25 \pm 0.52$ \\
\hline P. aeruginosa & $15 \pm 0.5$ \\
\hline S. typhimurium & $17 \pm 0.57$ \\
\hline
\end{tabular}

\subsection{Antibacterial Effects of M. anisodon}

The halo diameter of standed-growth in the presence of extracts was put in 10 groups based on mean comparison with Duncan test. The highest inhibition was seen in Pseudomonas aeruginosa at the concentration of $400 \mathrm{mg} / \mathrm{ml}$ of DMSO extract.

\section{DISCUSSION}

E. cephalotes had by far the highest amount of phenol among the plants in this study which may be due to the presence of coniferol (4.87\%). Plant organs in E. khuzistanicum had different total phenolic content, however, the flower and leaf contain the higher phenol concentration than the other organs. This could be due to the presence of 4-vinyl, 2-methoxy phenol (4.4\%) in flower of E. khuzistanicum. Maximum flavonoid content was determined in E. cephalotes and leaves of E. khuzistanicum. Given the importance of flavonoid compounds in the treatment of human diseases and the prevention of lipid oxidation in foods, high amounts of flavonoid in E. cephalotes and leaves of E. khuzistanicum is significant. M. anisodon and flower of E. khuzistanicum have high antioxidant activity in consensus with previous reports on the antioxidant activity in the genus of Marrubium and Echium [43-45]. There was no correlation between total phenolic content and antioxidant activity.

This activity occurs because of some compounds like phenols, flavonoids, and alkaloids in these plants. In general, the inhibitory effect on free radical DPPH depends on the type of solvent extraction, its polarity, separation method, purification of active components and method of measurement [46]. Molecular structure and position of the hydroxyl group on molecule determined antioxidant activity in flavonoid compounds [47]. Antioxidant activity in the plant was often evaluated by considering phenolic compound content. However, the antioxidant potential of the extracts does not solely depend on it. Terpenes are another major group of chemicals showed the antioxidant potential against DPPH radical scavenging activity 
which could be an additional contributory factor for antioxidant activity of extracts [48]. In flower of E. khuzistanicum and M. anisodon terpenes were detected (Tables 2 and 3). E. cephalotes have low percent inhibition effect on free radical DPPH despite the highest amount of phenol. It is possible to conclude that the antioxidant capacity observed doesn't only come from the phenolic contents but can occur because of some other phytochemicals such as ascorbic acid, tocopherol, terpenes and the synergistic effects of them, which also affect the total antioxidant capacity. On the other hand, various kinds of phenolic compounds depending on their structure show the different antioxidant activities. The extract of E. cephalotes possibly has different type of phenolic compounds with different antioxidant capacities [49].

The beneficial medicinal effect of a plant is due to the secondary metabolites in the plant [50-53]. There are alkaloids, flavonoids and phenolic compounds in the methanol extract of $E$. khuzistanicum flower according to GC/MS analysis that similar results have been described by Tiwari et al. (2011) [50]. The E. khuzistanicum root has an excellent antibacterial effect which can be attributed to the pigment (shikonin or alkannin) in the root of this family for which antibacterial properties was reported [54]. The antibacterial properties were reported in some genus of this family, for example, Tabata et al. (1982) showed that quinone derivatives of callus culture of Echium lycopsis have antimicrobial properties [54] and aqueous extract of Echium amoenum flower has anti-viral and anti-bacterial properties [55-56].

The type of solvent that is used in the extraction determines to a large extent the active compounds that are extracted from the plant [57]. The traditional physicians used the aqueous solvent for extraction, but the results of the research showed that the organic solvent in comparison with the aqueous solvent contains more anti-microbial compounds. Most of the active antimicrobial compounds that have been identified so far are not soluble in water, so organic solvents have a higher potential for having active antibacterial materials [58]. Watersoluble compounds such as polysaccharides and poly peptides, like all types of lectins, play a more effective role in preventing the absorption of pathogens and have no real effect like antimicrobial agents [59]. Water-soluble flavonoids, which are mostly anthocyanins, and watersoluble phenol compounds are only important as antioxidant compounds and do not have a specific antibacterial effect [60]. In this study, the methanol extract of the root as an organic solvent has the highest effect on the bacteria so it can be concluded that active polar compounds in methanol extract act as antibacterial agents.

M. anisodon did not show proper antibacterial properties in consensus with previous reports. Khalil et al. (2009) reported that Marrubium vulgare did not have antibacterial properties on Staphylococcus aureus and Pseudomonas aeruginosa [61]. Masoodi et al. (2008) have noted the antibacterial properties of the methanol extract of $M$. vulgare only in highly concentration of extract $(600 \mathrm{mg} / \mathrm{ml})$ [62]. Aerial parts of M. anisodon showed $27.7 \%$ inhibitory effect on the acetylcholinesterase activity which used for the treatment of Alzheimer's disease. This inhibitory effect was known related to some components that are functionally or structurally similar to the tacrine which can be alpha-pyrrolidone alkaloids in the chemical composition of this plant [30]. This family of the plant used to treat dandruff and hair regrowth [31]. According to the presence of vitamin B7 in this plant, it can be concluded that this is a good candidate for the treatment of hair loss and alopecia.

The extract of E. khuzistanicum can be used in food industries as a protective agent due to high antioxidant activity. This plant is widely used in traditional medicine and is a potential source of valuable compounds such as shikonin and unsaturated fatty acids [63]. This plant is a good candidate to replace the synthetic antibiotics due to good antibacterial properties are seen in this study. Screening, identification, and isolation of the active compounds in the plants and examining the toxicity of these compounds are considered as a way for the commercialization of these compounds. 
According to the results, the previous reports on the medicinal properties of the examined plants was confirmed by identification of compounds in the extract of these plants. The synthetic pathways of many secondary metabolites and associated genes in medicinal plants have not yet been completely identified. The amount of a particular secondary metabolite can be increased or decreased by identifying these synthetic pathways and genetic engineering of them. In these medicinal plants, there are valuable secondary metabolites such as alkaloids, flavonoids, diterpenes, unsaturated fatty acids, vitamin B and phenolic compounds which can be used in pharmaceutical and cosmetics industries.

\section{Orcid}

Samira Mohammadi (iD) https://orcid.org/0000-0002-1909-7717

Khosro Piri (iD https://orcid.org/0000-0002-9435-2378

Mehri Dinarvand (iD https://orcid.org/0000-0002-6824-3012

\section{REFERENCES}

[1]. Sharifi-Rad, M., Mnayer, D., Morais-Braga, M.F.B., Carneiro, J.N.P., Bezerra, C.F., Coutinho, H.D.M., Salehi, B., Martorell, M., del Mar Contreras, M., Soltani-Nejad, A. (2018). "Echinacea plants as antioxidant and antibacterial agents: From traditional medicine to biotechnological applications". Phytother. Res., vol 32, pp. 1653-1663.

[2] Ali, S.S., Kasoju, N., Luthra, A., Singh, A., Sharanabasava, H., Sahu, A., Bora, U. (2008). "Indian medicinal herbs as sources of antioxidants". Food. Res. Int., vol 41, pp. 1-15.

[3] Wu, C., Chen, F., Wang, X., Kim, H.-J., He, G.-q., Haley-Zitlin, V., Huang, G. (2006). "Antioxidant constituents in feverfew (Tanacetum parthenium) extract and their chromatographic quantification". Food. Chem., vol 96, pp. 220-227.

[4] Granato, D., Shahidi, F., Wrolstad, R., Kilmartin, P., Melton, L.D., Hidalgo, F.J., Miyashita, K., van Camp, J., Alasalvar, C., Ismail, A.B. (2018). "Antioxidant activity, total phenolics and flavonoids contents: should we ban in vitro screening methods?". Food. Chem, vol 264, pp. 471-475.

[5] Pokhrel, H., Baishya, S., Phukan, B., Pillai, D., Rather, M.A. (2018). "Occurrence and Distribution of Multiple Antibiotic Resistance Bacteria of Public Health Significance in Backwaters and Aquaculture Farm". Int. J. Curr. Microbiol. App. Sci., vol 7, pp. 975-987.

[6] O’Bryan, C.A., Crandall, P.G., Ricke, S.C. (2018). "Antimicrobial Resistance in Foodborne Pathogens, Food and Feed Safety Systems and Analysis", 1th ed.; Elsevier: Netherland, 2018; pp. 99-115; 9780128118351.

[7] Ali, M., Khan, T., Fatima, K., Ali, Q.u.A., Ovais, M., Khalil, A.T., Ullah, I., Raza, A., Shinwari, Z.K., Idrees, M. (2018). "Selected hepatoprotective herbal medicines: evidence from ethnomedicinal applications, animal models, and possible mechanism of actions". Phytother. Res., vol 32, pp. 199-215.

[8] Khatamsaz, M. (2002). "Flora of Iran: Boraginacea"3rd ed.; Research Institute of forests and rangelands: Tehran, 2002; pp. 78-85.

[9] Gao, H., Liu, L., Qu, Z.Y., Wei, F.X., Wang, S.Q. , Chen, G., Qin, L., Jiang, F.Y., Wang, Y.C., Shang, L., Gao, C.Y. (2011). "Anti-adenovirus activities of shikonin, a component of Chinese herbal medicine in vitro". Biol. Pharm. Bull., vol 34, pp. 197-202.

[10]Kim, J.Y., Jeong, H.J., Park, J.Y., Kim, Y.M., Park, S.J., Cho, J.K., Park, K.H., Ryu, Y.B., Lee, W.S. (2012). "Selective and slow-binding inhibition of shikonin derivatives isolated from Lithospermum erythrorhizon on glycosyl hydrolase 33 and 34 sialidases". Bioorg. Med. Chem., vol 20, pp. 1740-1748. 
[11]Lee, Y.J., Choi, S.Y., Yang, J.H. (2014). "NMDA receptor-mediated ERK 1/2 pathway is involved in PFHxS-induced apoptosis of PC12 cells". Sci. Total. Environ., vol 1, pp. 491492.

[12]Li, F., Yin, Z., Zhou, B., Xue, F., Yang, W., Chang, R., Ma, K., Qiu, Y. (2015). "Shikonin inhibits inflammatory responses in rabbit chondrocytes and shows chondroprotection in osteoarthritic rabbit knee". Int. Immunopharmacol, vol 29, pp. 656-662.

[13]Papageorgiou, V.P., Assimopoulou, A.N., Couladouros, E.A., Hepworth, D., Nicolaou, K.C. (1999). "The Chemistry and Biology of Alkannin, Shikonin, and Related Naphthazarin Natural Products". Angewandte. Chemie. International. Edition, vol 38, pp. 270-301.

[14] Skrzypczak, A., Przystupa, N., Zgadzaj, A., Parzonko, A., Syklowska-Baranek, K., Paradowska, K., Nalecz-Jawecki, G. (2015). "Antigenotoxic, anti-photogenotoxic and antioxidant activities of natural naphthoquinone shikonin and acetylshikonin and Arnebia euchroma callus extracts evaluated by the umu-test and EPR method". Toxicol. In Vitro, vol 30, pp. 364-372.

[15] Yang, Y., Wang, J., Yang, Q., Wu, S., Yang, Z., Zhu, H., Zheng, M., Liu, W., Wu, W., He, J., Chen, Z. (2014). "Shikonin inhibits the lipopolysaccharide-induced release of HMGB1 in RAW264.7 cells via IFN and NF-kappaB signaling pathways". Int. Immunopharmacol, vol 19, pp. 81-87.

[16]Fan, C., Xie, Y., Dong, Y., Su, Y., Upton, Z. (2015). "Investigating the potential of Shikonin as a novel hypertrophic scar treatment". J. Biomed. Sci., vol 22, pp. 1-13.

[17]Bursal, E., Aras, A., Kılıç, Ö. (2018). "Evaluation of antioxidant capacity of endemic plant Marrubium astracanicum subsp. macrodon: Identification of its phenolic contents by using HPLC-MS/MS". Nat. Prod. Res., vol pp. 1-5.

[18]Hymete, A., Iversen, T.H., Rohloff, J., Erko, B. (2005). "Screening of Echinops ellenbeckii and Echinops longisetus for biological activities and chemical constituents". Phytomedicine, vol 12, pp. 675-679.

[19] Ebrahimzadeh, M.A., Pourmorad, F., Bekhradnia, A.R. (2008). "Iron chelating activity, phenol and flavonoid content of some medicinal plants from Iran". Afr. J. Biotechnol., vol 7, pp.3188-3192.

[20]Chang, W.C.S., Soon, C.K., Bong, S.H., Hye, K.C., Min, J.A., Sang, H.P., Soo,K.K. (2002). "Antioxidant activity and free radical scavenging capacity between Korean medicinal plants and flavonoids by assay-guided comparison". Plant. Sci., vol 163, pp. 1161-1168.

[21] Singleton, V.L., Rossi, J.A. (1965). "Colorimetry of Total Phenolics with Phosphomolybdic-Phosphotungstic Acid Reagents." Am. J. Enol. Viticult., vol 16, pp. 144158.

[22] Shah, S.H.R, ZAhid, M., Mohammad, S., Mohammad. M.M., Aziz, U.R. (2016). "Evaluation of in vitro antioxidant and thrombolytic studies of some $\mathrm{N}-(2,3$-dihydro-1, 4benzodioxan-6-yl)-4-methylbenzenesulfonamide-N-acetamide derivatives". J. Chem. Pharm. Res., vol 8, pp. 424-431.

[23] Mangena, T., Muyima, N. (1999). "Comparative evaluation of the antimicrobial activities of essential oils of Artemisia afra, Pteronia incana and Rosmarinus officinalis on selected bacteria and yeast strains". Lett. Appl. Microbiol., vol 28, pp. 291-296.

[24] Shi, W., Marcus, S.L., Lowary, T.L. (2010). "Synthesis and antibacterial activity of aminosugar-functionalized intercalating agents". Carbohydr. Res., vol 345, pp. 10-22.

[25] Martinez, A., Rodriguez, M.E., Wells, M.L., York, S.W., Preston, J.F., Ingram, L.O. (2001). "Detoxification of dilute acid hydrolysates of lignocellulose with lime". Biotech. Prog., vol 17, pp. 287-293. 
[26]Boopathy, R., Bokang, H., Daniels, L. (1993). "Biotransformation of furfural and 5hydroxymethyl furfural by enteric bacteria". J. Ind. Microbiol, vol 11, pp. 147-150.

[27] Meyre-Silva,, Cechinel-Filho, V. (2010). "A review of the chemical and pharmacological aspects of the genus marrubium". Curr. Pharm. Des, vol 16, pp. 3503-3518.

[28]Karioti, A., Skaltsa, H., Heilmann, J., Sticher, O. (2003). "Acylated flavonoid and phenylethanoid glycosides from Marrubium velutinum". Phytochemistry, vol 64, pp. 655660 .

[29] Hussain, A., Perveen, S., Malik, A., Khan, A.N., Tareen, R.B. (2010). "Marrusidins A and B, New Epimeric Labdane Diterpenes from Marrubium anisodon". Helv. Chim. Acta, vol 93, pp. 1101-1104.

[30] Gholamhoseinian, A., Moradi, M., Sharifi-Far, F. (2009). "Screening the methanol extracts of some Iranian plants for acetylcholinesterase inhibitory activity". Res. Pharm. Sci., vol 4, pp. 105.

[31] Safaei, A. (2010). "Identification and quantitative determination of Luteolin and Apigenin in the aerial parts and an extract of Stachys lavandulifolia by HPLC". Iran. J. Pharm. Res., volume 3, pp. 90-90.

[32]Khan, I.A., Abourashed, E.A. (2009). "Leung's Encyclopedia of Common Natural Ingredients: Used in Food, Drugs and Cosmetics", $2^{\text {nd }}$ ed.; Wiley, New Jersey, Canada, 2009; pp. 511-520; 0471508268.

[33] Khan, R.A., Khan, M.R., Sahreen, S. (2012). "Assessment of flavonoids contents and in vitro antioxidant activity of Launaea procumbens". Chem. Central. J., vol 6, pp. 3-11.

[34]Khan, M.R., Marium, A., Shabbir, M., Saeed, N., Bokhari, J. (2012). "Antioxidant and hepatoprotective effects of Oxalis corniculata against carbon tetrachloride (CC14) induced injuries in rat". Afr. J. Pharm. Pharmacol., vol 6, pp. 30-37.

[35]Khan, I.A., Abourashed, E.A. (2011). "Leung's encyclopedia of common natural ingredients: used in food, drugs and cosmetics", $3^{\text {rd }}$ ed.; John Wiley $\&$ Sons, New Jersey, Canada, 2011;pp. 696-703; 9881607418.

[36] Javadzadeh, S. (1995). "The effect of sowing methods,"Nitrogen fertilizer, and plant density on quality and quantity yield of Borago officinalis LMS Thesis, Islamic Azad University of Jiroft, Iran , 1995.

[37]Bone, K., Mills, S. (2013). "Principles and Practice of Phytotherapy : Modern Herbal Medicine", 2nd ed.; Elsevier, USA, 2013; pp. 478-480; 978-0-443-06992-5.

[38] PadgeUe, S.R., Re, D.B., Barry, G.F., Eichholtz, D.E., Delannay, X., Fuchs, R.L., Kishore, G.M., Fraley, R.T. (2018). "New Weed Control Opportunities: Development of Soybeans with a Roundup Ready: Gene, Herbicide-resistant crops", $3{ }^{\text {rd }}$ ed.; CRC Press, Boca Raton, 2018; pp. 65-100; 9781351081641.

[39] Jacob, S. W, Lawrence, R. M, Zucker, M. (1999) "The Miracle of MSM". New York: Berkley Books.

[40]Delorme, P., Jay, M., Ferry, S. (1977). "Inventaire phytochimique des Borraginacees indigenes: etude des alcaloides et des composes polyphenoliques (composes anthocyaniques et flavoniques)". Plantes. Medicinales. et. Phytotherapie.

[41] Milos, M., Mastelic, J., Jerkovic, I. (2000). "Chemical composition and antioxidant effect of glycosidically bound volatile compounds from oregano (Origanum vulgare L. ssp. hirtum)". Food. Chem., vol 71, pp. 79-83.

[42]Ranjbar, A., Khorami, S., Safarabadi, M., Shahmoradi, A., Malekirad, A.A., Vakilian, K., Mandegary, A., Abdollahi, M. (2006). "Antioxidant Activity of Iranian Echium amoenum Fisch \& C.A. Mey Flower Decoction in Humans: A cross-sectional Before/After Clinical Trial". Evid. based. Complement. Altern. Med., vol 3, pp. 469-473. 
[43] Niciforovic, N., Solujic, S., Mihailovic, V., Pavlovic-Muratspahic, D. (2010). "In vitro antioxidant activity and tannin content of Echium italicum L". Planta. Med., vol 76, pp. $\mathrm{P} 248$.

[44]Edziri, H., Mastouri, M., Aouni, M., Verschaeve, L. (2012). "Polyphenols content, antioxidant and antiviral activities of leaf extracts of Marrubium deserti growing in Tunisia". S. Afr. J. Bot., vol 80, pp. 104-109.

[45]Anu, G., Usha, P. (2017). "Phytochemical screening and in vitro antioxidant study of chloroform soluble fraction of Thespesia populnea bark extract". J. Lives. Sci., vol 8, pp. 77-80.

[46] Škerget, M., Kotnik, P., Hadolin, M., Hraš, A.R., Simonič, M., Knez, Ž., (2005). "Phenols, proanthocyanidins, flavones and flavonols in some plant materials and their antioxidant activities". Food. Chem., vol 89, pp. 191-198.

[47]Karagözler, A.A., Erdağ, B., Emek, Y.Ç., Uygun, D.A. (2008). "Antioxidant activity and proline content of leaf extracts from Dorystoechas hastata". Food. Chem., vol 111, pp. 400-407.

[48] Majumdar, M., Parihar, P.S. (2012). "Antibacterial, anti-oxidant and antiglycation potential of Costus pictus from southern region, India". Asian. J. Plant. Sci. Res., vol 2, pp 95-102.

[49] Gupta, D., Kaul, V. (2017). " Antioxidant Activity Vis-a-Vis Phenolic Content in Leaves of Seabuckthorn from Kargil District (J\&K, India): A Preliminary Study". Natl. Acada. Sci. Lett., vol 40, pp. 53-56.

[50] Tiwari, P., Kumar, B., Kaur, M., Kaur, G., Kaur, H. (2011). "Phytochemical screening and extraction: a review". Int. pharm. Scie., vol 1, pp. 98-106.

[51]Eruygur, N., Ataş, M., Çevir, Ö., Tekin, M. (2017). "Investigating of Phytochemicals, Antioxidant, Antimicrobial and Proliferative Properties of Different Extracts of Thymus spathulifolius Hausskn. and Velen. Endemic Medicinal Plant from Sivas, Turkey". International Journal of Secondary Metabolite, vol 4 (3, Special Issue 1), pp. 155-166. DOI: $10.21448 / \mathrm{ijsm} .369775$

[52]Bektaş, E., Kaltalıoğlu, K., Şahin, H., Türkmen, Z., Kandemir, A. (2018). "Analysis of phenolic compounds, antioxidant and antimicrobial properties of some endemic medicinal plants". International Journal of Secondary Metabolite, vol 5 (2), pp. 75-86. DOI: 10.21448/ijsm.392354

[53] Shen, C.-C., Syu, W.-J., Li, S.-Y., Lin, C.-H., Lee, G.-H., Sun, C.-M. (1862). "Antimicrobial activities of naphthazarins from arnebia e uchroma". J. Nat. Prod., vol 65, pp. 1857-1862.

[54] Tabata, M., Tsukada, M., Fukui, H. (1982). "Antimicrobial activity of quinone derivatives from Echium lycopsis callus cultures". Planta. Med., vol 44, pp. 234-236.

[55] Abolhassani, M. (2010). "Antiviral activity of borage (Echium amoenum)". Archive of medical science: $A M S$, vol 6, pp. 366.

[56] Metrouh-Amir, H., Duarte, C.M., Maiza, F. (2015). "Solvent effect on total phenolic contents, antioxidant, and antibacterial activities of Matricaria pubescens". Ind. Crop. Prod., vol 67, pp. 249-256.

[57]Parekh, J., Jadeja, D., Chanda, S. (2006). "Efficacy of aqueous and methanol extracts of some medicinal plants for potential antibacterial activity". Turk. J. Biol., vol 29, pp. 203210.

[58]Cowan, M.M. (1999). "Plant products as antimicrobial agents". Clin. Microbiol. Rev., vol 12, pp. 564-582.

[59] Nang, H., May, C.Y., Ngan, M., Hock, C.C. (2007). "Extraction and identification of water soluble compounds in Palm Pressed Fiber by SC-CO2 and GC-MS". Am. J. Environ. Sci., vol 3, pp. 54-59. 
[60] Yamaji, K., Ishimoto, N., Usui, H., Mori, S. (2005). "Organic acids and water-soluble phenolics produced by Paxillus sp. 60/92 together show antifungal activity against Pythium vexans under acidic culture conditions". Mycorrhiza, vol 15, pp. 17-23.

[61] Khalil, A., Dababneh, B.F., Al-Gabbiesh, A.H. (2009). "Antimicrobial activity against pathogenic microorganisms by extracts from herbal Jordanian plants". J. Food. Agric. Env., vol 7, pp. 103-106.

[62] Masoodi, M.H., Ahmed, B., Zargar, I.M., Khan, S.A., Khan, S., Singh, P. (2008). "Antibacterial activity of whole plant extract of Marrubium vulgare". Afri. J. Biotechnol., vol 7, pp.086-087.

[63] Mohammadi. S., Piri, Kh. (2014). " Antifungal effects of two medicinal plant native to Iran". Int. J. Adv. Biol. Biomed. Res., vol 2, pp. 2712-2715. 